\title{
PERAN KELOMPOK TANI ORA ET LABORA DALAM PENINGKATAN PRODUKTIVITAS USAHATANI PADI SAWAH DI KELURAHAN TARATARA SATU
}

\author{
Syntia Pandey \\ Melsje Yellie Memah \\ Jean Fanny Junita Timban
}

\begin{tabular}{ll}
\hline Naskah diterima melalui Website Jurnal Ilmiah agrisosioekonomi@ unsrat.ac.id & : Senin, 22 April 2019 \\
Disetujui diterbitkan & : Jumat, 26 April 2019 \\
\hline
\end{tabular}

\begin{abstract}
This study aims to determine how the role of Ora et Labora Farmers Group in increasing the productivity of wetland rice farming in Taratara Satu Village, Tomohon Barat District, Tomohon City. The Ora et Labora Farmer Group was choose purposevly and all the board members and members of the Farmer Group as respondents. This study used primary data and secondary data. Primary data was carried out by direct interviews with 10 farmers who were members and board members of the Ora et Labora Farmer Group. Secondary data was obtained from the Taratara Satu Village Office in Tomohon Barat Subdistrict, local bookstores, the internet through google scholar to get electronic books, journal articles and theses that related to the research topic on the role of Farmer Groups in increasing productivity of lowland rice farming. The data analysis method used in this study is descriptive analysis and then interpreted to draw conclusions. The results showed that there was an increase in farm productivity compared to before joining the Ora et Labora farmer group. Ora et Labora farmer group has played a role in increasing the productivity of rice farming in farmer groups in Taratara Satu Village, Tomohon Barat Subdistrict, Tomohon City, therefore was classified to the good category. ${ }^{*}{ }^{*}$ rm*
\end{abstract}

Keywords : role, farming productivity, rice

\begin{abstract}
ABSTRAK
Penelitian ini bertujuan untuk mengetahui bagaimana peran Kelompok Tani Ora et Labora dalam meningkatkan produktivitas usahatani padi sawah di Kelurahan Taratara Satu, Kecamatan Tomohon Barat, Kota Tomohon. Metode pengambilan sampel secara sengaja hanya Kelompok Tani Ora et Labora yaitu pada semua pengurus dan anggota Kelompok Tani. Penelitian ini menggunakan data primer dan data sekunder. Data primer dilakukan dengan wawancara langsung dengan 10 petani yang merupakan anggota dan pengurus Kelompok Tani Ora et Labora. Data sekunder diperoleh dari Kantor Kelurahan Taratara Satu Kecamatan Tomohon Barat, toko buku lokal, internet melalui google scholar untuk mendapatkan buku elektronik, artikel jurnal dan skripsi yang berkaitan dengan topik penelitian tentang peran Kelompok Tani dalam peningkatan produktivitas usahatani padi sawah. Metode analisis data yang digunakan dalam penelitian ini yaitu analisis deskriptif kemudian diinterpretasi untuk penarikan kesimpulan. Hasil penelitian menunjukkan bahwa terjadi peningkatan produktivitas usahatani dibandingkan dengan sebelum bergabung dengan kelompok tani Ora et Labora. Kelompok tani Ora et Labora telah berperan dalam meningkatkan produktivitas usahatani padi di kelompok tani Kelurahan Taratara Satu Kecamatan Tomohon Barat Kota Tomohon sehingga tergolong dalam kategori baik. ${ }^{* e p r m *}$
\end{abstract}

Kata kunci : peran, produktivitas usahatani, padi sawah

\section{PENDAHULUAN}

\section{Latar Belakang}

Petani adalah pokok utama dalam pertanian. Mengapa demikian, karena petani memainkan peran sebagai inti dalam pembangunan pertanian. Petanilah yang memelihara tanaman dan menentukan bagaimana meningkatkan produktivitas usahataninya. Dengan kata lain, petani menjadi pokok dalam peningkatan semua hal berkaitan dengan pertanian. Melampaui itu, pada akhirnya petani harus mempelajari dan menerapkan metode - metode baru yang 
diperlukan untuk membuat usaha tani-nya agar lebih produktif. Di samping itu, tentu saja petani jugalah yang sangat berperan dan menjadi motor yang bisa menggerakkan produktivitas usahatani-nya.

Tidak jarang terjadi juga bahwa terdapat petani yang suka membentuk satu kelompok tani yang kenyataannya akan semakin meningkatkan produktivitas hasil pertaniannya. Realitas ini juga menegaskan bahwa setiap individu (petani) tidak akan dapat memenuhi kebutuhan berkaitan dengan produktivitas hasil pertanian. Bahkan dalam masyarakat modern ini, kebersamaan dalam sebuah kelompok juga turut menunjang kekurangan yang bisa saja dimiliki oleh individu atau oleh si petani itu. Dalam kaitan dengan hal tersebut, di Keluarahan Taratara Satu terdapat beberapa kelompok tani yang tumbuh dan berkembang sampai saat ini. Berkaitan dengan hal itu juga, fokus penulis dalam penelitian ini adalah bagaimana produktivitas petani sawah di Kelurahan Taratara Satu khususnya di kelompok tani Ora Et Labora. Jumlah penduduk, penduduk Kelurahan Taratara Satu pada tahun 2014 berjumlah 1813 jiwa dengan kepala keluarga 493 (KK) dan semuanya Warga Negara Indonesia. Kelurahan Taratara Satu sebagian besar penduduknya mempunyai mata pencaharian rata-rata adalah petani $(85 \%)$ ini dapat dilihat dari kawasan perkebunan masyarakat yang ditanami pohon kelapa, cengkeh, serta terdapat daerah persawahan dan ladang yang ditanami padi dan jagung serta komoditi hortikultura lainnya. Para tani mengerjakannya secara kelompok maupun perorangan, sehingga di kelurahan Taratara satu mempunyai kelompok tani.

Masyarakat setempat sebagian besar bermata pencaharian petani atau dalam bidang bercocok tanam, hal tersebut memberikan gambaran terhadap tingkat pendapatan yang berbeda pada deretan status ekonomi lemah, oleh karena itu masyarakat menggunakan cara pertaniaannya yang masih sederhana dan baru sebagian kecil yang menca pai pada penggunaan tehnologi modern sekarang ini, begitu juga sistem yang belum terlalu mendukung dalam peningkatan masalah pertaniaan.

Berdasarkan uraian diatas maka peneliti saat ini ingin mengetahui bagaimana peran kelompok tani Ora et Labora dalam peningkatan usahatani padinya yang berada di Kelurahan Taratara Satu Kecamatan Tomohon Barat.

Berdasarkan Peraturan Mentri Pertanian No. 82 Permentan/ OT. 140/ 8/ 2013 Klasifikasi Kemampuan Poktan adalah pemeringkatan kemampuan kelompoktani ke dalam 4 (empat) kategori yang terdiri dari: kelas pemula, kelas lanjut, kelas madya dan kelas utama yang penilaiannya berdasarkan kemampuan kelompok tani. Perluh diketahui bersama bahwa di Kelurahan Taratara Raya tercatat di Dinas Pertanian Kota Tomohon, ada 61 kelompok pertanian dengan berbagai macam komoditi atau komoditas unggulan yang terbagi juga dalam beberapa klasifikasi kelas kemampuan. Tercatat ada 30 kelompok tani yang masuk dalam kelas pemula, dan ada 25 kelompok tani yang masuk dalam kelas lanjut serta ada 6 kelompok tani yang masuk dalam kelas madya.

Peran kelompok tani berdasarkan pada Peraturan Menteri Pertanian Nomor.67/ Permentan/ SM. 050/ 12/ 2016, dalam upaya peningkatan kemampuan kelompok tani dalam melaksanakan perannya sebagai berikut: (a). Kelas Belajar, kelompok tani merupakan wadah belajar mengajar bagi anggota yang guna meningkatkan pengetahuan, keterampilan dalam berusaha tani; (b)WahanaKerjasama, kelompoktani merupakan tempat untuk memperkuat kerjasama diantara sesama petani dalam kelompok tani dan antar kelompok tani serta dengan pihak lain; (c)Unit Produksi, sebagai unit produksi, kelompok tani diarahkan untuk memiliki kemampuan mengambil keputusan dalam menentukan pengembangan produksi yang menguntungkan.

Peran adalah konsep tentang apa yang harus dilakukan oleh individu dalam masyarakat dan meliputi tuntutan-tuntutan 
perilaku dari masyarakat terhadap seseorang dan merupakan perilaku individu yang penting bagi struktur sosial masyarakat (Wulansari, 2009).

Kelompok tani adalah petani yang dibentuk atas dasar kesamaan kepentingan kesamaan kondisi lingkungan (sosial, ekonomi, sumberdaya) keakraban dan keserasian yang dipimpin oleh seorang ketua (Trimo, 2006).

Menurut Mardikanto (1993) kelompok tani diartikan sebagai kumpulan orang-orang tani atau yang terdiri dari petani dewasa (pria/wanita) maupun petani taruna (pemuda/pemudi) yang terikat secara formal dalam suatu wilayah keluarga atas dasar keserasian dan kebutuhan bersama serta berada di lingkungan pengaruh dan pimpinan seorang kontak tani.

Ilmu usahatani adalah ilmu yang mempelajari bagaimana seseorang mengalokasikan sumber daya yang ada secara efektif dan efisien untuk memperoleh keuntungan yang tinggi pada waktu tertentu. Dikatakan efektif bila petani dapat mengalokasikan sumber daya yang mereka miliki sebaik-baiknya, dan dapat dikatakan efisien bila pemanfaatan sumber daya tersebut mengeluarkan output yang melebihi input (Shinta, 2011).

Produktivitas yaitu mengandung pengertian sebagai sikap mental yang selalu berpandangan bahwa mutu kehidupan hari ini harus lebih baik dari kemarin dan esok harus lebih baik dari hari ini. Filosofi dan spirit tentang produktivitas sudah ada sejak awal peradaban manusia karena makna produktivitas adalah keinginan (the will) dan upaya (effort) manusia untuk selalu meningkatkan kualitaskehidupan dan penghidupan di segala bidang (Maurits, 2010).

Produktivitas dipengaruhi oleh suatu kombinasi dari banyak faktor antara lain kualitas bibit, pupuk, jenis teknologi yang digunakan, ketersediaan modal, kualitas infrastruktur dan tingkat pendidikan /pengetahuan petani/buruh tani. Selain faktor faktor tersebut praktek manajemen (pemupukan, pemberian pestisida dan sebagainya) juga sangat mempengaruhi produktivitas (Suparmi, 2009)

\section{Rumusan Masalah}

Berdasarkan uraian pada latar belakang maka dapat dirumuskan permasalahan sebagai berikut: Bagaimana peran Kelompok Tani dalam peningkatan produktivitas usahatani padi di Kelurahan Taratara Satu Kecamatan Tomohon Barat, Kota Tomohon?

\section{Tujuan Penelitian}

Tujuan dari penelitian ini adalah untuk mengetahui bagaimana peran Kelompok Tani dalam peningkatan produktivitas usahatani padi sawah Kelompok Tani Ora Et Labora di Kelurahan Taratara Satu.

\section{Manfaat Penelitian}

1. Sebagai bahan informasi bagi petani dan investor/pemilik sawah.

2. Sebagai bahan masukan bagi pemerintah dan instansi terkait lainnya dalam mengambil kebijakan, khususnya yang berhubungan dengan kelompok tani di Kelurahan Taratara

\section{METODE PENELITIAN}

\section{Waktu dan TempatPenelitian}

Penelitian ini dilakukan di Kelurahan Taratara Satu, Kecamatan Tomohon Barat, Kota Tomohon. Penelitian berlangsung selama 7 bulan mulai dari November 2018 sampai Mei 2019. Adapun tahap-tahap itu dimulai dari tahap persiapan, pengambilan data sampai pada penyusunan laporan hasil penelitian.

\section{Metode Pengumpulan Data}

Metode pengumpulan data dalam penelitian ini menggunakan data primer (data yang diperoleh peneliti secara langsung) dan data sekunder (data yang diperoleh peneliti dari sumber yang sudah ada) dari Pemerintah Kecamatan Tomohon Barat. 


\section{Metode Pengambilan Sampel}

Metode pengambilan sampel anggota kelompok tani dalam penelitian ini adalah dengan menggunakan metode sampling yang studinya disebut studi populasi atau studi sensus. Sensus ini dilakukan di kelompok tani Ora Et Labora yang berjumlah 10 responden.

\section{Konsep Pengukuran Variabel}

Variabel, sub variabel dan indikator penelitian yang dikaji dalam penelitian ini adalah:

1. Ciri dan faktor petani, meliputi :
a. Umur
b. Pendidikan
c. Status Usahatani
d. Luas Lahan
e. Status Penguasaan Lahan
f. Intensitas Terkena Penyuluhan
g. Pengalaman Berusahatani

2. Peran Kelompok Tani
a. Wahana belajar dan berorganisasi
b. Wahana Kerjasama
c. Unit produksi usahatani

3. Produktifitas Usahatani

\section{Analisis Data}

Metode analisis data yang digunakan dalam penelitian ini yaitu analisis deskriptif kemudian diinterpretasi untuk penarikan kesimpulan

\section{Metode Penelitian}

Metode penelitian yang digunakan dalam penelitian ini yaitu menggunakan metode penelitian kualitatif.

\section{HASIL DAN PEMBAHASAN}

\section{Deskripsi Wilayah Penelitian}

Adapun tempat penelitian yang menjadi objek penelitian adalah Kelurahan Taratara Satu yang berada di Kecamatan Tomohon Barat, Kota Tomohon, Provinsi Sulawesi Utara. Kelurahan Taratara Satu dengan letak geografis berada pada 010 19'00 s/d 010 21'32', Lintang Utara dan 1240 44'
10" s/d 1240 46'50" Bujur Timur. Dengan batas-batas wilayahnya :

Sebelah Utara : Gunung Kasehe

Sebelah Selatan : Perkebunan Sawa

Sebelah Timur : Kelurahan Taratara Dua

Sebelah Barat : Kelurahan Taratara

\section{Sejarah Kelompok Tani Ora Et Labora}

Kelompok tani Ora et Labora sudah berdiri sejak tahun 2014 pada tanggal 5 Februari yang beranggotakan masyarakat petani yang sebagian merupakan pemilik lahan dan sebagiannya lagi merupakan penggarap. Lokasi kelompok tani ini berada di areal perkebunan yang bernama Kai Tombal, wilayah perkebunan Kelurahan Taratara Satu, Kecamatan Tomohon Barat, Kota Tomohon.

Jumlah anggota kelompok dan pengurus kelompok tani Ora Et Labora sebanyak 10 orang yang terdiri dari 9 orang laki-laki dan 1 orang perempuan. Kelompok tani ini dibawah pembinaan Petugas Penyuluh Lapangan Dinas Pertanian Kota Tomohon.

\section{Karakteristik Responden}

Tabel 1 merupakan data dari 10 responden berdasarkan jenis kelamin, jabatan dalam kelompok tani, luas lahan yang di kelolah oleh responden serta jumlah tanggungan dalam keluarga oleh responden.

\begin{tabular}{|c|c|c|c|c|c|}
\hline No. & Nama & $\mathrm{L} / \mathrm{P}$ & Jabatan & $\begin{array}{c}\text { Luas } \\
\text { Lahan } \\
(\mathrm{Ha})\end{array}$ & $\begin{array}{c}\text { Jumlah } \\
\text { Tangu } \\
\text { ngan } \\
\text { (Orang) }\end{array}$ \\
\hline 1 & Jopij Victory Lonta & $\mathrm{L}$ & Ketua & 00.07 & 5 \\
\hline 2 & Ronal A Rotikan & $\mathrm{L}$ & Sekretaris & 00.04 & 3 \\
\hline 3 & Raymond Datu & $\mathrm{L}$ & Bendahara & 00.09 & 3 \\
\hline 4 & Sam A. Aror & $\mathrm{L}$ & Anggota & 00.05 & 5 \\
\hline 5 & Yohanis Pontoan & $\mathrm{L}$ & Anggota & 00.05 & 2 \\
\hline 6 & Benedikta Paat & $\mathrm{P}$ & Anggota & 00.07 & 4 \\
\hline 7 & Jhony D. Morong & $\mathrm{L}$ & Anggota & 00.05 & 3 \\
\hline 8 & Ruben Taroreh & $\mathrm{L}$ & Anggota & 00.07 & 2 \\
\hline 9 & Boby Lendeng & $\mathrm{L}$ & Anggota & 00.07 & 4 \\
\hline 10 & Estevanus Sambow & $\mathrm{L}$ & Anggota & 00.05 & 3 \\
\hline \multicolumn{6}{|c|}{ Sumber : Data Primer, 2019} \\
\hline
\end{tabular}
Karakteristik responden sangat berhubungan dengan peningkatan produktivitas usahatani padi dari petani dan dari data yang diperoleh menunjukan bahwa anggota kelompok tani Ora Et Labora dapat digolongkan dalam usia produktif. 


\begin{tabular}{lll} 
Tabel 2. Responden Berdasarkan Umur & & \\
\hline Umur & Jumlah & Persentasi \% \\
\hline Non Produktif < 15 tahun dan > 65 Tahun & 0 & 0 \\
Produktif 15 - 65 Tahun & 10 & 100 \\
\hline Total & 10 & 100 \\
\hline Sumber : Data Primer, 2019 & &
\end{tabular}

Pendidikan merupakan salah satu faktor yang sangat menentukan juga dalam peningktan produktivitas karena semakin tinggi tingkat pendidikan anggota kelompok tani semakin baik juga bagi anggota kelompok tani dalam menyerap maupun mengadopsi materi-materi yang diberikan oleh penyuluh untuk meningatkan usahataninya. Dapat dilihat pada Tabel 3.

Tabel 3. Responden Berdasarkan Pendidikan

\begin{tabular}{lcc}
\hline \multicolumn{1}{c}{ Tingkat } & Jumlah & Persentase \% \\
\hline SD & 2 & 20 \\
SMP & 1 & 10 \\
SMA/SMK & 7 & 70 \\
Perguruan Tinggi & 0 & 0 \\
\hline Total & 10 & 100 \\
\hline
\end{tabular}

Sumber : Data Primer, 2019

Dari Tabel 4 dapat dilihat bahwa sebagian besar anggota kelompok tani merupakan pemilik lahan padi sawah yaitu sebanyak $80 \%$ dan hanya ada $20 \%$ anggota kelompok tani yang berstatus penggarap.

Tabel 4. Status Penguasaan Lahan

\begin{tabular}{lcc}
\hline $\begin{array}{c}\text { Status Penguasaan } \\
\text { Lahan }\end{array}$ & Jumlah & Persentase \% \\
\hline Milik Sendiri & 8 & 80 \\
Sewa & 0 & 0 \\
Bagi Hasil & 0 & 0 \\
Menggarap & 2 & 20 \\
\hline Total & 10 & 100 \\
\hline Sumber : Data Primer, 2019 & &
\end{tabular}

Hasil produktivitas usahatani juga dapat ditentukan berdasarkan lamanya petani/anggota kelompok terjun atau berkecimpung di pertanian. Dapat dilihat pada Tabel 5.

Tabel 5. Lama Berusahatani

\begin{tabular}{lcc}
\hline Lama Berusahatani & Jumlah & Persentase \% \\
\hline Lebih dari 5 Tahun & 10 & 100 \\
Kurang dari 5 Tahun & 0 & 0 \\
\hline Total & 10 & 100 \\
\hline
\end{tabular}

\section{Peran Kelompok Tani}

\section{Wahana Belajar dan Beroganisasi}

Kelompok tani sebagai wahana belajar dan berorganisasi merupakan suatu wadah bagi setiap anggota kelompok untuk saling berinteraksi guna meningkatkan pengetahuan, keterampilan, dan sikap dalam berusahatani sehingga dapat meningkatkan kemampuan dalam melakukan usahatani (Setiadin dalam Istiyani, 2015).

Tabel 6. Lama Bergabung Dengan Kelompok Tani

\begin{tabular}{lcc}
\hline $\begin{array}{l}\text { Lama Bergabung } \\
\text { dengan kelompok tani }\end{array}$ & Jumlah & Persentase \% \\
\hline Lebih dari 3 tahun & 9 & 90 \\
Kurang dari 3 tahun & 1 & 10 \\
\hline Total & 10 & 100 \\
\hline Sumber : Data Primer, 2019 & &
\end{tabular}

Tabel 6 menunjukkan bahwa dari semua responden hanya ada 1 petani yang bergabung dengan kelompok tani kurang dari 3 tahun. Karena petani tersebut merupakan penggarap sehingga petani tersebut baru bergabung dengan kelompok

Tabel 7. Kelompok Tani Sering Mengadakan Pelatihan Penyuluhan

\begin{tabular}{lcc}
\hline $\begin{array}{l}\text { Kelompok tani sering mengadakan } \\
\text { pelatihan penyuluhan }\end{array}$ & Jumlah & $\begin{array}{c}\text { Persentase } \\
\%\end{array}$ \\
\hline Ya & 10 & 100 \\
Tidak & 0 & 0 \\
\hline Total & 10 & 100 \\
\hline Sumber : Data Primer, 2019 & &
\end{tabular}

Tabel 7 menunjukkan bahwa 100\% responden menjawab kelompok tani sering mengadakan pelatihan penyuluhan. Pelatihan penyuluhan kepada petani atau anggota kelompok tani sangat penting dalam peningkatan produktivitas usahataninnya.

Tabel 8. Seberapa Sering Pertemuan Kelompok Tani

\begin{tabular}{lcc}
\hline $\begin{array}{l}\text { Seberapa sering pertemuan } \\
\text { kelompok tani }\end{array}$ & Jumlah & $\begin{array}{c}\text { Persentase } \\
\%\end{array}$ \\
\hline Tidak Pernah & 0 & 0 \\
Harian & 0 & 0 \\
Mingguan & 0 & 0 \\
Bulanan & 10 & 100 \\
\hline Total & 10 & 100 \\
\hline Sumber : Data Primer, 2019 & &
\end{tabular}

Kelompok tani Ora Et Labora sering melakukan pertemuan setiap bulan. Pertemuan ini dalam bentuk diskusi dengan anggota kelompok. Mendiskusikan jika petani menghadapi masalah maka kelompok tani yang memberikan solusi 
bagaiamana cara menghadapi masalah tersebut. Peran kelompok tani dalam mengdakan pertemuan sangat penting dalam peningkatan usahatani padi petani.

Tabel 9. Siapa Pelaksana Pelatihan Atau Penyuluhan

\begin{tabular}{lcc}
\hline $\begin{array}{l}\text { Siapa pelaksana pelatihan } \\
\text { penyuluhan }\end{array}$ & Jumlah & $\begin{array}{c}\text { Persentase } \\
\%\end{array}$ \\
\hline Penyuluh & 10 & 100 \\
Instansi Pemerintah lain & 0 & 0 \\
Perguruan Tinggi & 0 & 0 \\
LSM & 0 & 0 \\
\hline Total & 10 & 100 \\
\hline Sumber $:$ Data Primer (diolah) & &
\end{tabular}

Sumber : Data Primer (diolah)

Tabel 9 menunjukkan bahwa di kelompok tani Ora Et Labora yang sering melaksanakan pelatihan penyuluhan hanya tim penyuluh dari Pemerintah Kota Tomohon.

Tabel 10. Bentuk Penyampaian Materi

\begin{tabular}{lcc}
\hline Bentuk Penyampaian materi & Jumlah & Persentase \% \\
\hline Pemaparan & 8 & 80 \\
Demonstrasi & 0 & 0 \\
Diskusi & 2 & 20 \\
Pemberian Modul & 0 & 0 \\
\hline Total & 10 & 100 \\
\hline
\end{tabular}

Sumber : Data Primer, 2019

Tabel 10 menunjukkan bahwa bentuk penyampaian materi dalam bentuk pemaparan mencapai $80 \%$ dan $20 \%$ dalam bentuk diskusi. Anggota kelompok tani saat ini sudah tidak pernah mendapatkan modul.

Tabel 11. Wahana Belajar Dan Berorganisasi

\begin{tabular}{lcc}
\hline Wahana Belajar dan Beroganisasi & Jumlah & Persentase \% \\
\hline Sangat Setuju & 9 & 90 \\
Setuju & 1 & 10 \\
Ragu-ragu & 0 & 0 \\
Tidak Setuju & 0 & 0 \\
\hline Total & 10 & 100 \\
\hline Sumber : Data Primer, 2019 & &
\end{tabular}

Tabel 11 menunjukkan bahwa Persentase dari 15 pernyataan yang bertujuan untuk mengetahui bagaimana pendapat dari seluruh responden terhadap wahana belajar dan berorganisasi di kelompok tani. Termasuk ada $80 \%$ responden yang sangat setuju jika kelompok tani perlu di buat atau dibentuk di setiap desa dan kelurahan. Responden juga setuju jika petani masuk atau bergabung dengan kelompok tani. Karena kelompok tani juga bisa membantu petani dalam penyelesaian masalah. Dari hasil penelitian, responden juga setuju jika pertemuan kelompok tani sering diadakan setiap bulannya disesuaikan dengan waktu luang dari petani. Dari hasil penelitian $50 \%$ responden menjawab setuju jika kegiatan kelompok tani sudah terarah dengan baik sedangkan sisanya 50\% menjawab raguragu karena, menurut responden kelompok tani saat ini sudah jarang mengadakan pertemuan. Selain penyuluhan, kelompok tani juga mengadakan pelatihan dan kunjungan guna menambah pengetahuan anggota kelompok tani dan $80 \%$ responden mejawan setuju dengan hal tersebut. karena menurut responden akan sangat membantu jika kelompok tani sering mengadakan pertemuan untuk mendiskusikan masalah yang terjadi dalam proses pengolahan padi sawah oleh petani dan dalam kelompok tani Ora Et Labora saat ini sudah jarang mendatangkan penyuluh untuk penyampaian materi, namun kelompok tani Ora Et Labora sampai saat ini masih sering mengadakan pertemuan dengan anggota kelompok dan sering mendiskusikan bagiamana peningkan usahatani oleh anggota kelompok.

\section{Wahana Kerjasama}

Tabel 12 menunjukkan bahwa peran kelompok tani dalam bidang wahana kerjasama masih kurang. Kelompok tani hanya bekerjasama dengan lembaga sarana produksi pertanian dalam penyediaan bibit dan pupuk. Kelompok tani memberikan bantuan handtractor kepada seluruh anggota dalam membantu mengurangi biaya sewa ditempat lain. Dalam mengolah hasil produksi padi sawah milik petani, kelompok tani tidak bekerja sama dengan lembaga pemasaran hasil produksi karena anggota kelompok tani sendiri yang mengolah langsung hasil produksinya. Begitupun dalam pemasarannya, kelompok tani juga tidak bekerja sama dengan pihak pasar karena dalam pemasaran padi yang sudah diolah menjadi beras petani tidak sepenuhnya menjual semua hasil panen mereka ke pasar. Melainkan untuk dikonsumsi sendiri dan sebagiannya dijual ke masyarakat sekitar, jadi tidak lansung ke pasar.

Tabel 12 Sebagai Wahana Kerjasama

\begin{tabular}{|c|c|c|c|}
\hline $\begin{array}{l}\text { Sebagai } \\
\text { Kerjasama }\end{array}$ & Wahana & Jumlah & Persentase $\%$ \\
\hline Baik & & 0 & 0 \\
\hline Kurang & & 10 & 100 \\
\hline Total & & 10 & 100 \\
\hline
\end{tabular}




\section{Unit Produksi Usahatani}

Kelompok tani sebagai unit produksi usahatani merupakan suatu kesatuan usaha yang dapat dikembangkan untuk mencapai skala ekonomis usaha, dengan menjaga kuantitas, kualitas maupun kontinuitas (Permentan dalam Istiyani, 2015).

Unit produksi usahatani terbagi dalam dua kompenen yang terdiri dalam 11 indikator pernyataan untuk dijawab oleh setiap responden yaitu penyedia sarana dan prasarana serta pengolahan dan pemasaran.

\begin{tabular}{llccccc}
\multicolumn{7}{l}{ Tabel 13. Penyedia Sarana dan Prasarana } \\
\hline No & Penyedia Sarana Prasarana & SS & S & R & TS & Jumlah \\
\hline 1 & $\begin{array}{l}\text { Kelompok tani memberikan } \\
\text { bantuan bibit untuk ditanam }\end{array}$ & 7 & 3 & & 10 \\
2 & $\begin{array}{l}\text { Kelompok tani memberikan } \\
\text { bantuan pupuk untuk petani }\end{array}$ & 6 & 4 & & 10 \\
3 & $\begin{array}{l}\text { Kelompok tani menyediakan } \\
\text { bantuan pestisida bagi petani }\end{array}$ & 6 & 4 & 10 \\
4 & $\begin{array}{l}\text { Kelompok tani menyediakan } \\
\text { bantuan modal dana bagi petani }\end{array}$ & 3 & 7 & 10 \\
5 & $\begin{array}{l}\text { Kelompok tani menyediakan } \\
\text { peralatan untuk membantu } \\
\text { melakukan budidaya mediakan }\end{array}$ & 2 & 8 & & 10 \\
6 & $\begin{array}{l}\text { Kelompok tani menyediakan } \\
\text { bantuan akses pasar }\end{array}$ & 8 & 2 & 10 \\
\hline Sumber : Data Primer, 2019 & & &
\end{tabular}

Tabel 13 menunjukkan bahwa sebagian besar responden menjawab sangat setuju jika kelompok tani memberikan bantuan bibit, pupuk maupun pestisida bagi petani. Karena hal tersebut akan sangat membantu petani dalam hal meningkatkan produksi usahatani padi sawah mereka. Dalam kelompok tani Ora Et Labora sudah melakukan hal tersebut. Kelompok tani ini memberikan bantuan bibit maupun pupuk setiap memasuki musim tanam yang baru. Begitupun dalam penyedian modal dana bagi petani dan penyedian alat untuk membantu melakukan budidaya, sebagian besar responden menjawan setuju akan hal tersebut.

\begin{tabular}{|c|c|c|c|c|c|c|}
\hline No & Pengolahan dan Pemasaran & SS & $\mathrm{S}$ & $\mathrm{R}$ & TS & Jumlah \\
\hline 1 & $\begin{array}{l}\text { Kelompok } \begin{array}{l}\text { tani } \\
\text { pengolahan } \\
\text { panen) }\end{array} \text { hasil pertanian (pasca } \\
\end{array}$ & 1 & 9 & & & 10 \\
\hline 2 & $\begin{array}{l}\text { Kelompok tani memiliki fasilitas yang } \\
\text { memadai untuk melakukan } \\
\text { pengolahan hasil panen }\end{array}$ & & 9 & 1 & & 10 \\
\hline 3 & $\begin{array}{l}\text { Kelompok tani secara kolektif } \\
\text { melakukan pengolahan hasil pertanian }\end{array}$ & & 9 & 1 & & 10 \\
\hline 4 & $\begin{array}{l}\text { Kelompok tani } \quad \text { membantu } \\
\text { memasarkan hasil produk oalahan ke } \\
\text { pasar }\end{array}$ & & 9 & 1 & & 10 \\
\hline 5 & $\begin{array}{l}\text { Kelompok tani memberikan hasil } \\
\text { penjualan produk yang seimbang } \\
\text { dengan harga pasar }\end{array}$ & & 9 & & 1 & 10 \\
\hline
\end{tabular}

Tabel 14 menunjukkan bahwa sebagian besar yaitu sebanyak 9 responden setuju jika pengolahan dan pemasaran dilakukan oleh kelompok tani. Sesuai dengan hasil penelitian penulis yang terjun langsung dalam pengambilan data di lapangan, penulis mendapati bahwa di kelompok tani Ora Et Labora dalam hal pengolahan dan pemasaran hasil produk petani anggota kelompok tani belum teralisasikan. Jadi hal itu terjadi karena belum ada pembicaraan baik kelompok tani dengan anggota kelompok dalam hal pengolahan hasil produksi padi sawah mereka, karena hasil panen dari petani diolah sendiri oleh petani pemilik maupun penggarap, dan setelah diproses menjadi beras, hasil tersebut dimanfaatkan untuk dikonsumsi dan sebagian hasil panen dijual jika ada yang mau membeli.

\section{Produktivitas Usahatani}

Produktivitas usahatani pada penelitian ini dikaji berdasarkan perbandingan hasil pertanian yang dihasilkan petani dalam bentuk beras pada saat sebelum bergabung dan setelah bergabung dengan kelompok tani. Produktivitas usahatani pada penelitian ini diperoleh berdasarkan data temuan di lapangan.

\begin{tabular}{|c|c|c|c|c|}
\hline \multirow[t]{2}{*}{ No } & \multicolumn{2}{|c|}{ Luas Lahan (Ha) } & \multicolumn{2}{|c|}{ Hasil Panen $(\mathrm{Kg})$} \\
\hline & $\begin{array}{c}\text { Sebelum } \\
\text { Bergabung }\end{array}$ & $\begin{array}{c}\text { Sesudah } \\
\text { Bergabung }\end{array}$ & $\begin{array}{c}\text { Sebelum } \\
\text { Bergabung }\end{array}$ & $\begin{array}{c}\text { Sesudah } \\
\text { Bergabung }\end{array}$ \\
\hline 1 & 00.07 & 00.07 & 800 & 1002 \\
\hline 2 & 00.04 & 00.04 & 700 & 900 \\
\hline 3 & 00.09 & 00.09 & 1000 & 1350 \\
\hline 4 & 00.05 & 00.05 & 900 & 1500 \\
\hline 5 & 00.05 & 00.05 & 500 & 800 \\
\hline 6 & 00.07 & 00.07 & 2009 & 3000 \\
\hline 7 & 00.05 & 00.05 & 600 & 800 \\
\hline 8 & 00.07 & 00.07 & 2000 & 2900 \\
\hline 9 & 00.07 & 00.07 & 1800 & 2400 \\
\hline \multirow[t]{2}{*}{10} & 00.05 & 00.05 & 700 & 1000 \\
\hline & Total Hasil Pa & & 11009 & 15652 \\
\hline
\end{tabular}

Tabel 15 menunjukkan bahwa rekapan dari hasil panen padi yang sudah diolah menjadi beras sebelum responden bergabung dengan kelompok tani dan sesudah responden bergabung dengan kelompok tani.

Tabel 16. Persentase Produktivitas Usahatani

\begin{tabular}{lcc}
\hline Kategori & Jumlah & Persentase \% \\
\hline Menurun & 0 & 0 \\
Meningkat & 10 & 100 \\
\hline Total & 10 & 100 \\
\hline Sumber : Data Primer, 2019 &
\end{tabular}


Tabel 16 menunjukkan bahwa Persentase kategori produktivitas usahatani padi sawah oleh seluruh responden yang dapat dilihat bahwa seluruh responden mengalami peningkatan hasil panen dari sebelum bergabung dan sesudah bergabung dengan kelompok tani.

Berdasarkan hasil wawancara, petani mengalami peningkatan dikarenakan petani mulai menerapkan pola tanam yang sudah diberikan oleh tim penyuluh. Disamping itu petani juga memberikan pupuk anorganik ataupun organik yang disarankan oleh kelompok tani.

\section{KESIMPULAN DAN SARAN}

Peran $\begin{aligned} & \text { Kesimpulan } \\ & \text { kelompok tani dalam }\end{aligned}$
meningkatkan produktivitas usahatani padi di kelompok tani Ora Et Labora Kelurahan Taratara Satu Kecamatan Tomohon Barat Kota Tomohon digolongkan dalam kategori baik. Hal ini dapat dilihat dari peningkatan produktivitas usahatani dari petani yang meningkat dari sebelum bergabung dengan kelompok tani.

Kelompok $\begin{array}{r}\text { Saran } \\ \text { tani harus lebih }\end{array}$
meningkatkan lagi perannya dalam hal mengadakan pertemuan, diskusi anggota kelompok tani, dan lebih sering menghadirkan tim penyuluh guna memberikan ilmu atau pengetahuan dalam meningkatkan produktivitasnya. Pemberian bibit serta pupuk kepada petani pun kiranya boleh terus dijalankan agar produktivitas usahataninya boleh terus ditingkatkan.

\section{DAFTAR PUSTAKA}

Istiyani, A.. 2015. Peranan Kelompok Tani Dalam Meningkatkan Produktivitas Usahatani Anggota. Studi Pustaka, 2(3).

Mardikanto, T. 1993. Penyuluhan Pembangunan Pertanian. Sebelas Maret University Press. Surakarta.

Maurits L S K. 2010. Selintas Tentang Kelelahan Kerja. Yogyakarta: Amara Books.

Shinta, Agustina. 2011. Ilmu Usahatani. Universitas Brawijaya Press, Malang.

Suparmi dan A. Sahri. 2009. Kajian pemanfaatan sumber daya rumput laut dari aspek industri dan kesehatan. Sultan Agung Vol XLIV N0. 96: 1-18.

Trimo. 2006. Evaluasi Penyuluhan Pembangunan Pertanian. Surakarta: UNS Press.

Wulansari, D. (2009). Sosiologi (Konsep dan Teori), Bandung: PT. Refika Aditama. 